Dhaka Univ. J. Biol. Sci. 19(1): 27-40, 2010 (January)

\title{
EDAPHIC CONDITIONS OF DIFFERENT ISLANDS UNDER DIFFERENT HYDROLOGICAL REGIMES IN THE COASTAL ZONE OF BANGLADESH
}

\author{
Ashfaque Ahmed*, Mikael Ohlson, Sirajul Hoque ${ }^{1}$ and Md. Golam Moula ${ }^{2}$ \\ Department of Ecology and Natural Resource Management, \\ Norwegian University of Life Sciences, Ås-1432, Norway
}

Key words: Edaphic conditions, Coastal zone, Hydrological regimes, Tidal amplitude

\begin{abstract}
Physical and chemical properties of soils from the southern coastal zone of Bangladesh were studied to understand the effect of inundation on different soil variables. Soil samples were collected from three different islands representing different hydrological regimes, viz. Char Motherbunia (Island I) is inundated twice daily, Char Taposhi (Island II) is inundated by high tide and Char Kashem (Island III) is totally raised, inundated only during storm surges. Three transects in each island perpendicular to the river Buragauranga were established. Five soil samples, each with a composite of five sub-samples, were collected from each transect, 15 variables were tested from total 15 samples of each island. To test the variations among the islands and within the island, ANOVA was used. Soils of the three islands were found to be rather similar in chemical properties, although there were some significant differences in $\mathrm{pH}$ and potassium concentration. The results indicated that broad-scale hydrology did not effect the variation found in the edaphic condition rather duration and amplitude may be responsible for some observed variation. A correlation matrix of the soil variables showed a strong correlation among chemical elements and that the majority of elements were significantly correlated with $\mathrm{pH}$.
\end{abstract}

\section{Introduction}

The coast has had a long but uneasy relationship with man. But throughout its history human being has concentrated towards the coastal plains and lowland river valley.(1) Currently about $60 \%$ of the world's population is living near the coast. ${ }^{(2)}$ The role of coast towards human benefit has been shifted from food and security provider to industrial and commercial development to more recently towards leisure and conservation. The coastal resources of Bangladesh are of great importance for a large human population living there. The green belt created at the different island at the coastal zones by the afforestation program of the Forest Department protected the huge population from different natural calamities such as Tsunami, cyclones and storm surges etc. which lashes the area frequently. Yet, there is no comprehensive

*Corresponding author. Present address: Ecology and Environment Laboratory, Department of Botany, University of Dhaka, Dhaka-1000, Bangladesh. <aashfaque67@yahoo.com>. 1Department of Soil, Water and Environment, University of Dhaka, Bangladesh, ${ }^{2}$ Plantation Trial Unit Division, Bangladesh Forest Research Institute, Rupatali, Barisal, Bangladesh. 
survey to determine the oceanographic features, edaphic conditions and organic productivity of the Bay of Bengal and its estuary. Consequently, there is a general lack of basic information on the structure and function of coastal ecosystems of the country. Some fragmentary data are, however, available on the primary productivity of the deeper part and shelf area of the Bay that owe to the Indian Ocean Expedition $^{(3,4)}$ that started in the 1880s.

This study examines the affect of different hydrological conditions on the edaphic features of different islands (chars) in the coastal zone of Bangladesh with an assumption that soils of different islands will show variability in its physico-chemical parameters due to fluctuation of tidal inundation. There are only a few earlier studies that reports on the physical and chemical properties of the soil from offshore islands $s^{(5,6,7)}$ and there are no studies that provide detailed information on physicochemical properties of the soils on offshore islands representing different hydrological conditions. This paper presents the first detailed description of soil properties on offshore islands as affected by inundation in the coastal zone of Bangladesh.

\section{Materials and Methods}

Geomorphology of the study area: The coastal areas of Bangladesh are divided into three distinct regions: the western, central and eastern coastal zones. The western part is characterized by numerous criss-crossed channels and creeks, the central zone, where the present study was conducted, is featured by the discharges of the three mighty rivers (Ganges, Brahmaputra and Meghna) and is an area of continuous process of accretion and erosion that made the area most active among the three zones. ${ }^{(8)}$

Climate: Tropical maritime climate prevails in the coastal zones. ${ }^{(9)}$ The mean temperature in the coastal areas varies between $19^{\circ} \mathrm{C}$ in winter and $29^{\circ} \mathrm{C}$ in summer. The amount of rainfall varies from about $3,000 \mathrm{~mm}$ in the west, down to $2,300 \mathrm{~mm}$ in the centre and as high as $4,000 \mathrm{~mm}$ in the east. Average monthly humidity values ranged between 71 and 92\% (Data were collected from the Climate division, Bangladesh Meteorological Department, Government of the People's Republic of Bangladesh for 1985 to 2005).

Dynamics of the study area: The coastal zone and islands included in the present study are shown in Fig. 1. Thematic mapper (TM) images from Landsat, prepared by Bangladesh Space Research and Remote Sensing Organization (SPARRSO), showed the dynamics of the river bed and vegetation pattern of the study area (Figs. 2a-b). Images were collected from Bangladesh Space Research and Remote Sensing Organization of different years from 1989 to 2006 (images of 1989 and 2006 are shown only). It is clear from the image of 1989 (Fig. 2a) that one of the islands, namely Char Taposhi, was in the early stage of land accretion. Plantation started in 


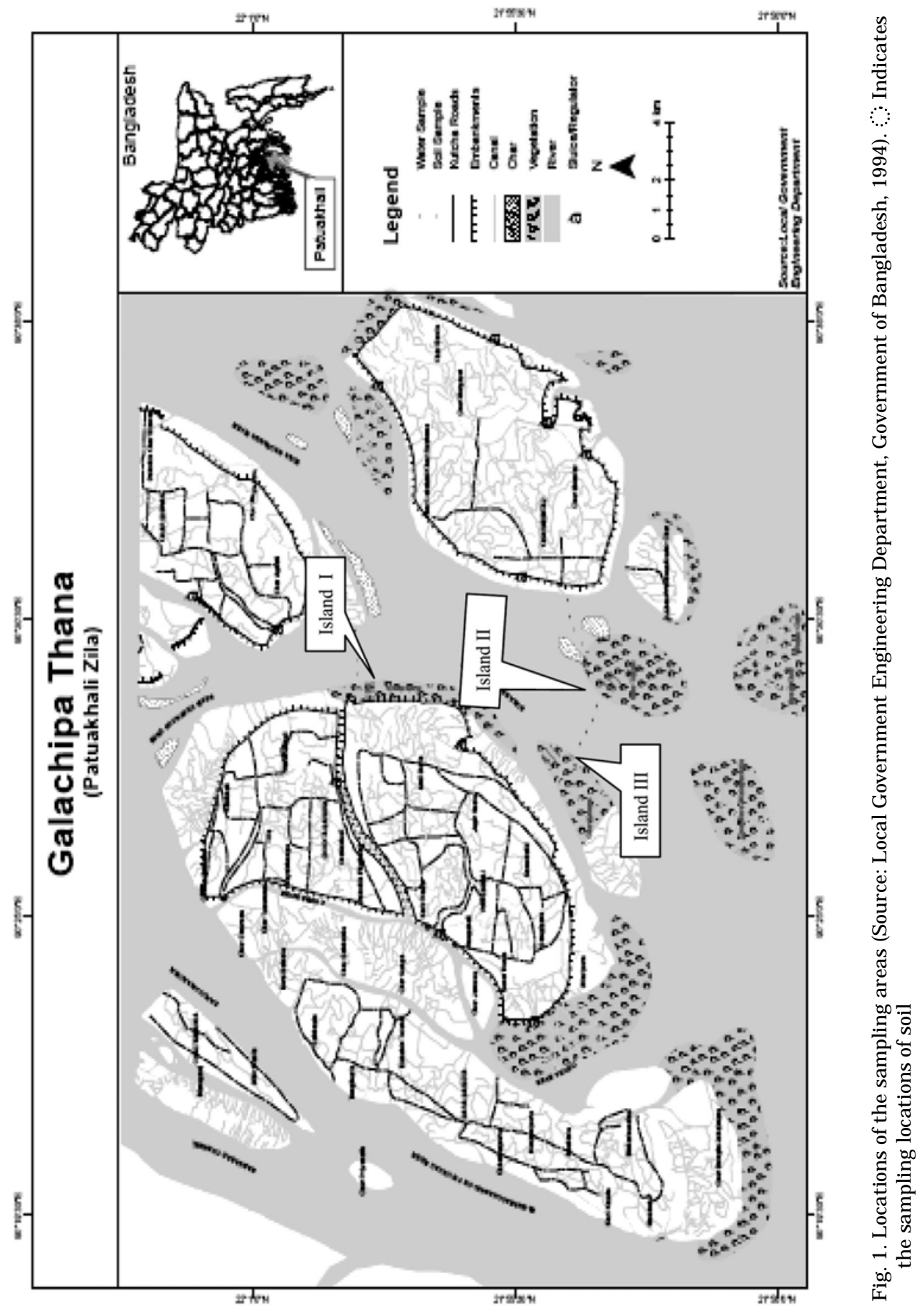


that char in 1987. In 1992, the char was distinctly visible and about $70 \%$ of the char of current size was formed. Land is still accreted there towards the south i.e. seawards direction. Numerous new chars are being raised and it is becoming a continuous strip. New land is accreted to the eastern boundary of the Char Motherbunia making the channel narrower and flow of the river in this channel seems to be blocked in near future as numerous chars are rising at the mouth of the channel, at the northern part of the Rangabali police station (Fig. 2b).

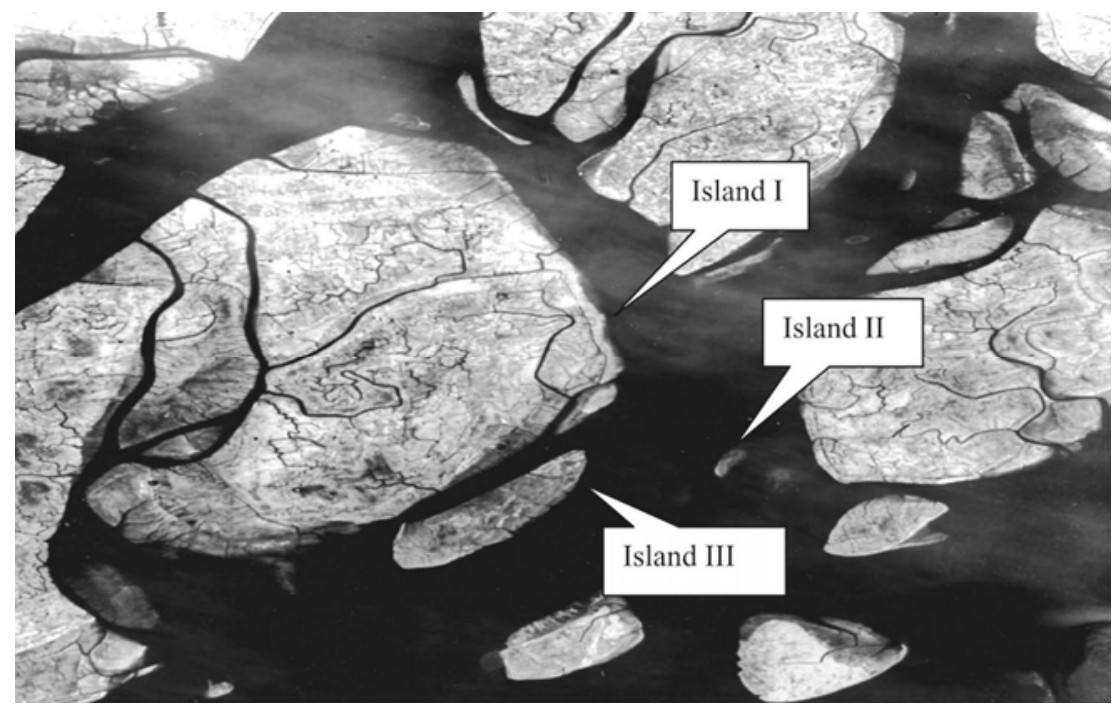

Fig. 2a. Thematic mapper image from Land Sat of the study area taken in 1989 (Source SPARRSO).

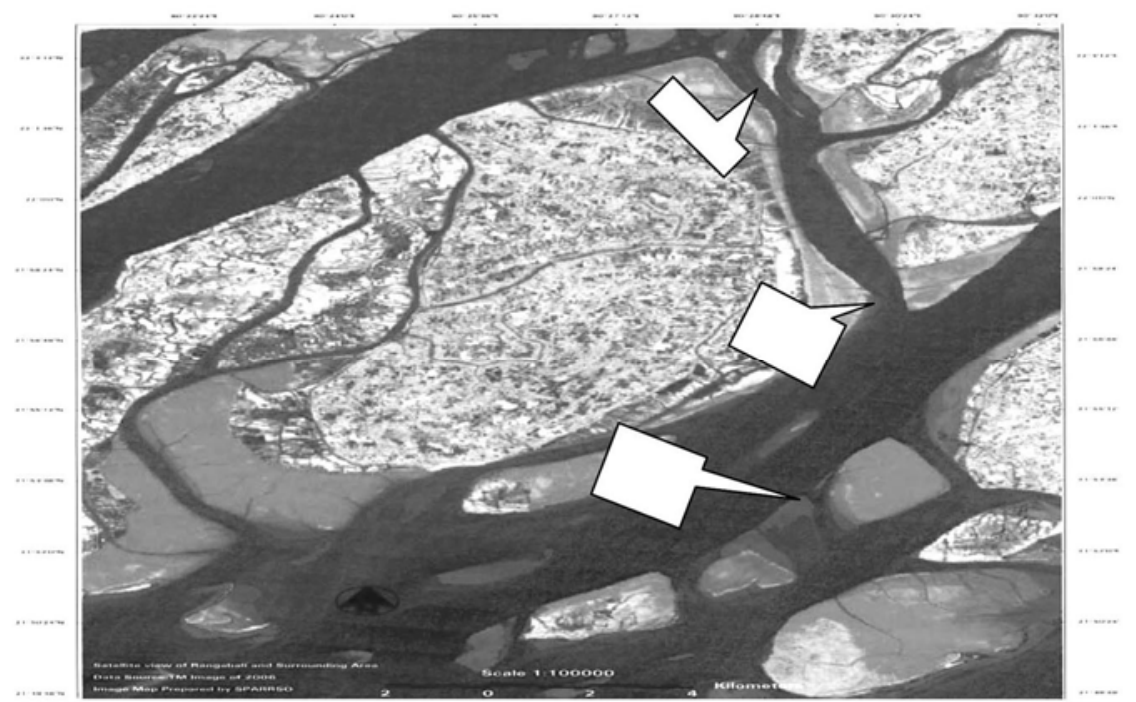

Fig. 2b. 'Thematic mapper image trom Land Sat of the study area taken in zuv6 (Source SPARRSO). 
Sample collection: Soil samples were collected from a segment of the coast at the Rangabali Police Station (administrative unit) of Galachipa upazila (sub district) of Patuakhali district $\left(21^{\circ} 53^{\prime} 10^{\prime \prime}-22^{\circ} 0^{\prime} 0^{\prime \prime} \mathrm{N}\right.$ and $\left.90^{\circ} 27^{\prime} 0^{\prime \prime}-90^{\circ} 30^{\prime} 30^{\prime \prime} \mathrm{E}\right)$. Soil samples were collected on 27th February, 2006 from three different islands (chars) with different hydrological regime.

Three chars (islands), namely Char Motherbunia (hereinafter referred to as Island I) (latitude $21^{\circ} 56^{\prime} 48^{\prime \prime}-21^{\circ} 58^{\prime} 24^{\prime \prime} \mathrm{N}$ and longitude $90^{\circ} 28^{\prime} 48^{\prime \prime}-90^{\circ} 29^{\prime} \mathrm{E}$ ), Char Taposi (hereinafter referred to as Island II) (latitude $21^{\circ} 52^{\prime}-21^{\circ} 54^{\prime} 18^{\prime \prime} \mathrm{N}$ and longitude $90^{\circ} 29^{\prime}-90^{\circ} 30^{\prime} 48^{\prime \prime} \mathrm{E}$ ) and Char Kashem (hereinafter referred to as Island III) (latitude $21^{\circ} 52^{\prime}-21^{\circ} 54^{\prime} 18^{\prime \prime} \mathrm{N}$ and longitude $90^{\circ} 25^{\prime}-90^{\circ} 27^{\prime} 48^{\prime \prime} \mathrm{E}$ ), were selected from the central coastal zone, amongst numerous Islands raised along the coastal area of Bangladesh (Figs. 2a-b and for sampling areas Fig. 1). These three islands were selected as they represent three different hydrological regimes due to frequencies of tidal inundations. The Island I is inundated twice daily. In case of Island II and Island III, these chars are raised totally where Island II is inundated in high tide and Island III is not inundated except storm surges. Soil samples were collected from five points along a line and three lines were demarcated beside the river Buragauranga from each island (Fig. 1). From each point five sub samples were collected and mixed thoroughly to make a composite sample. Thus a total of 15 samples, consisting of 75 sub samples were collected from each island. The distance between two sampling points was $200 \mathrm{~m}$ and between two lines was about $200 \mathrm{~m}$. In the Island I, the first line was demarcated on the recently (one year) accreted land, the second line was on the land accreted about two years and third line was on the three year old land.

Analytical methods: Soil $\mathrm{pH}$ was determined by using fresh soil to water (distilled water) ratio of $1: 2.5$ with the help of a $\mathrm{pH}$ meter (Jenway). Twenty gram fresh soil was leached with $100 \mathrm{ml}$ deionized distilled water maintaining $1: 5$ ratios and the conductivity of the leachate was measured by electrical conductivity meter. Water soluble $\mathrm{Na}^{+}$and $\mathrm{K}^{+}$were determined by flame photometer (Jenkin,UK). Calcium and $\mathrm{Mg}$ as ions were determined by atomic absorption spectrophotometer. Water soluble $\mathrm{S}$ as $\mathrm{SO}_{4}^{2-}$ was measured by the turbidimetric method of Hunt.(10) One gram air dried soil sample was digested with nitric acid-perchloric acid mixture $(2: 1)$. $^{(11)}$ Phosphorus content of the digest was determined by vanadomolybdophosphoric yellow colour method in nitric acid system as described by Jackson (1973).(12) Total K was determined by flame photometer. Total $\mathrm{S}$ content of the digest was determined by turbidimetric method.(10) Total $\mathrm{N}$ of the soil was determined by the modified Kjeldahl method as described by Jackson. ${ }^{(12)}$ Water soluble chloride was determined titrimetrically with standard $0.05 \mathrm{~N}$ silver nitrate solution. Organic C (\%) was determined by Walkley and Black's wet oxidation method. (13) Organic matter content was calculated from the organic carbon value by multiplying with a factor 
1.724. Soil samples were analysed at Soil Chemistry Laboratory of Soil, Water and Environment Department, University of Dhaka, Bangladesh.

Statistical analysis: Different variables of each soil samples were subjected to analysis of variance (ANOVA). Island and location were used as factors. To compare soil samples among the islands and locations, ANOVA was performed using general linear model procedures in SAS 9.1 program. Interactions between islands and locations were also tested for soil samples. Pearson correlations were calculated for soil sample variables.

\section{Results and Discussion}

Physical and chemical properties of soils: Soil moisture differed among the islands as well as locations. Island I and II were characterized by relatively high soil moisture i.e. 44 and $42 \%$, respectively whereas the corresponding figure for Island III was significantly lower $(\mathrm{p}<0.0001)$ averaging $28 \%$ (Fig. 3). The mean moisture content in the soils of the study areas was $38 \%$ with minimum and maximum values of 24 and $64 \%$, respectively (Table 1). There were no significant differences between the locations 1 and 2 in Island I but these two locations differed significantly from location $3(\mathrm{p}=0.0001)$. The three locations of the Islands II and III did not show significant differences among them (Fig. 4). The interaction between islands and locations was significant $(p=0.0046)$ for moisture content (Table 2 ).

There were no significant differences among the three islands as regard to total nitrogen $\left(\mathrm{N}_{\text {tot }}\right)$, total phosphorus $\left(\mathrm{P}_{\mathrm{tot}}\right)$ and total sulfur $\left(\mathrm{S}_{\mathrm{tot}}\right)$ contents, but these islands differed significantly $(\mathrm{p}<0.0001)$ in total potassium $\left(\mathrm{K}_{\mathrm{tot}}\right)$ and water soluble potassium $\left(\mathrm{K}_{\mathrm{ws}}\right)$ content and electrical conductivity (EC) (Table 2). As regard to $\mathrm{pH}$, $\mathrm{Cl}-\mathrm{C}$, organic matter $(\mathrm{OM}), \mathrm{Ca}_{\mathrm{ws}}$ and $\mathrm{Na}_{\mathrm{ws}}$, Island I differed significantly $(\mathrm{p}=0.0016$, $\mathrm{p}<0.0001, \mathrm{p}=0.015, \mathrm{p}=0.015, \mathrm{p}=0.001$ and $\mathrm{p}=0.008$, respectively) from Island II and III, which in turn did not differ from each other in these variables. Island III differed significantly from Island I and II in Mgws content $(p=0.004)$ and no such difference was found between Island I and II. Highest value of conductivity (16.0 $\mathrm{dS} / \mathrm{m}$ ) was found in location 2 of Island III. Significant interactions between islands and locations were found in case of $\mathrm{N}_{\text {tot }}, \mathrm{C}, \mathrm{OM}$ and $\mathrm{S}_{\text {tot }}$ (Table 2). For example, maximum mean total nitrogen content $(0.11 \%)$ was found in location 1 in Island I followed by location $2(0.07 \%)$ and location $3(0.07 \%)$, whereas maximum values were found in location 3 in two other Islands $(0.12$ and $0.12 \%)$ which were followed by locations 1 and 2 in Island II and locations 2 and 1 in island III. The values of overall mean, median, minimum and maximum values of the overall data and values of interaction between island and location of different parameters are given in Tables 1

and 2. 

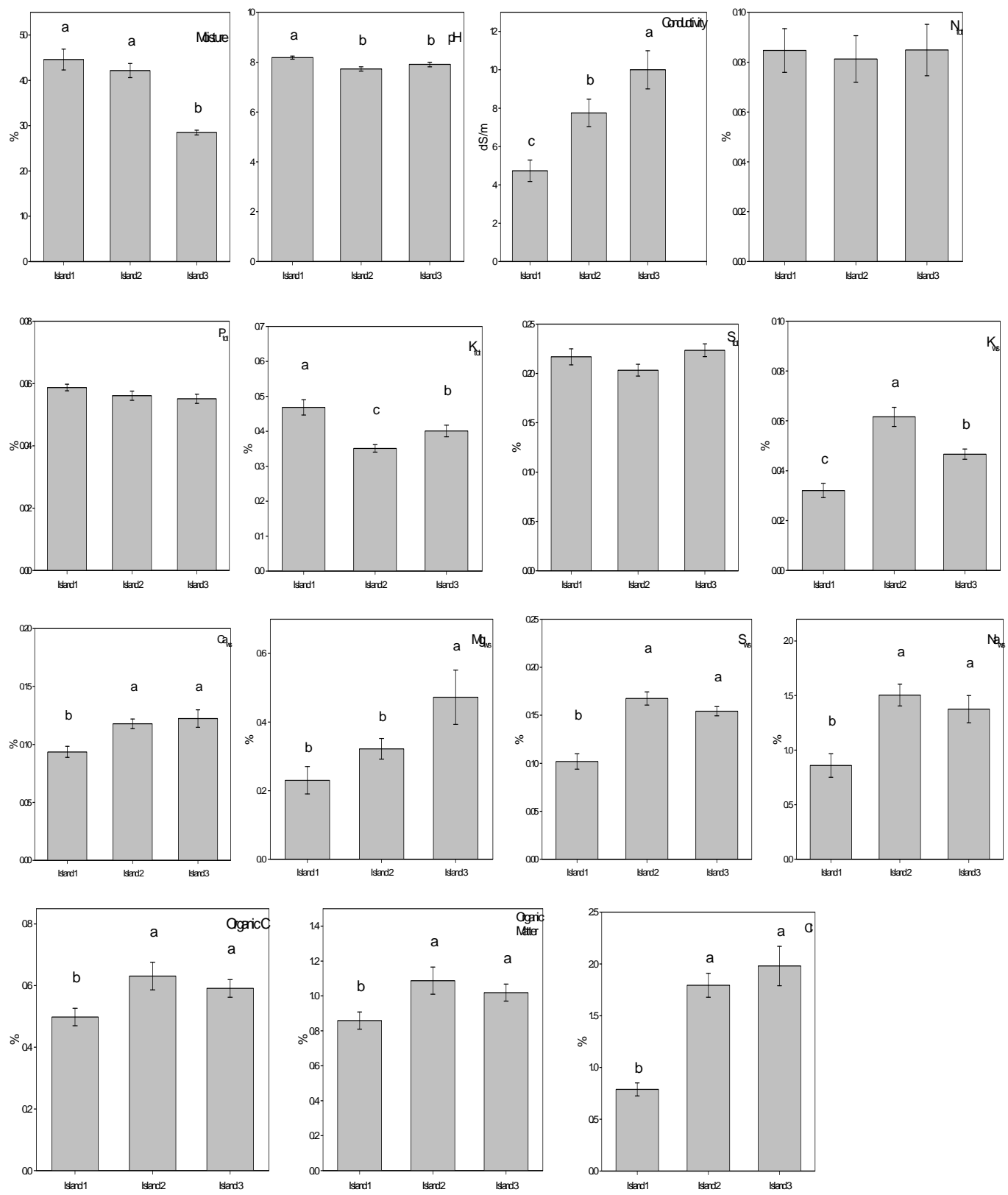

Fig. 3. Variations in mean values (per cent) of different elements with \pm 1 standard error present in soil samples in three different islands. tot stands for total and wsstands for water soluble. Different letters at the top of the bars showed that they are significantly different at the $\mathrm{p}=0.05$ level. 
Table 1. Descriptive statistics of different variable of soils of the overall study area. Cond. $=$ Conductivity, $O M=$ Organic matter, tot and ws are explained in the text.

\begin{tabular}{lcrrrrrr}
\hline Variable & Count & \multicolumn{1}{c}{ Mean } & SE mean & Coef Var & Minimum & Median & Maximum \\
\hline Moisture(\%) & 45 & 38.40 & 1.41 & 24.64 & 24.22 & 37.93 & 63.94 \\
pH & 45 & 7.94 & 0.05 & 4.52 & 6.67 & 7.95 & 8.99 \\
Cond. (dS/m) & 45 & 7.49 & 0.55 & 48.84 & 3.00 & 7.00 & 16.00 \\
N $_{\text {tot }}(\%)$ & 45 & 0.084 & 0.005 & 43.00 & 0.02 & 0.074 & 0.165 \\
Ptot $_{\text {t\%) }}$ & 45 & 0.057 & 0.001 & 9.39 & 0.276 & 0.386 & 0.638 \\
Stot $_{\text {t\%) }}$ & 45 & 0.215 & 0.004 & 12.83 & 0.161 & 0.22 & 0.305 \\
Kws $(\%)$ & 45 & 0.047 & 0.002 & 35.72 & 0.016 & 0.043 & 0.084 \\
Caws $(\%)$ & 45 & 0.111 & 0.004 & 22.46 & 0.054 & 0.109 & 0.167 \\
Mgws(\%) & 45 & 0.342 & 0.032 & 62.95 & 0.111 & 0.287 & 1.016 \\
Sws $\%)$ & 45 & 0.141 & 0.006 & 27.05 & 0.064 & 0.148 & 0.237 \\
Naws $(\%)$ & 45 & 1.246 & 0.075 & 40.61 & 0.431 & 1.157 & 2.23 \\
C $(\%)$ & 45 & 0.573 & 0.021 & 24.99 & 0.394 & 0.513 & 0.908 \\
OM $(\%)$ & 45 & 0.988 & 0.037 & 24.98 & 0.679 & 0.884 & 1.565 \\
Cl- $(\%)$ & 45 & 1.520 & 0.109 & 48.50 & 0.485 & 0.143 & 3.415 \\
\hline
\end{tabular}

The three sampling locations of each island showed significant variations in some parameters (Fig. 4). For example, in case of Island 1, the $\mathbf{N}_{\text {tot }}$ content of location 1 varied significantly ( $p=0.023$ and $p=0.0115$ respectively) from locations 2 and 3 . Location 3 had significant variations $(\mathrm{p}=0.0021$ and $\mathrm{p}=0.0021)$ from locations 1 and 2 in case of Sws content and the values of locations 1 and 2 were almost similar. Other parameters of three locations did not show significant differences.

In Island II, $\mathrm{C}$ and OM content of location 2 and 3 varied significantly $(\mathrm{p}=0.0115)$ from location 1, whereas locations 2 and 3 had non-significant difference between them. The amount of $\mathrm{N}_{\text {tot }}$ varied non significantly in between locations 1 and 3 but they were significantly different from location $2(p=0.01, p=0.02)$. In case of $\mathrm{S}_{\text {tot }}$, location 2 and 3 had similar values whereas location 3 varied significantly from location $1(p=0.0028)$ but location 2 did not have significant difference with location 1. Sws content of the three locations followed the same pattern as $\mathrm{C}$ and OM. Other parameters did not show significant differences among the locations.

The values of $\mathrm{EC}, \mathrm{N}_{\text {tot }}, \mathrm{C}, \mathrm{OM}$, and $\mathrm{Mg}_{\mathrm{ws}}$ showed significant variations among the three locations of Island III., where conductivity and $\mathrm{Mg}_{\mathrm{ws}}$ followed a common trend. Location 2 showed significant difference from locations 1 and $3(\mathrm{p}=0.0056, \mathrm{p}=$ $0.0051, \mathrm{p}=.0049$ and 0.016 , respectively). $\mathrm{N}_{\text {tot }}, \mathrm{C}$ and $\mathrm{OM}$ content, followed another pattern where the values of location 3 were significantly different from locations 1 and 2. These two locations had comparable non-significant difference.

Pearson's correlations of soil variables showed that all soil variables except $\mathrm{N}_{\text {tot }}$ and $\mathrm{S}_{\text {tot, }}$ had significant correlation with $\mathrm{pH}$ (Table 3). Positive correlations were 
found for $\mathrm{pH}$ with moisture content, $\mathrm{P}_{\text {tot }}$ and $\mathrm{K}_{\mathrm{tot}}$, otherwise all correlations were negative. $\mathrm{N}_{\text {tot }}$ had significant positive correlation with $\mathrm{Ca}_{\mathrm{ws}}$, organic $\mathrm{C}$ and organic matter. $\mathrm{P}_{\text {tot }}$ showed significant positive correlations with $\mathrm{K}_{\text {tot. }}$ On the other hand $\mathrm{K}_{\text {tot }}$ showed negative significant correlation with water soluble $\mathrm{K}, \mathrm{Na}, \mathrm{S}$ and $\mathrm{Ca}$. Organic $\mathrm{C}$ and organic matter had no correlation with $\mathrm{P}_{\text {tot }}$ and $\mathrm{K}_{\text {tot. }} \mathrm{Mg}_{\mathrm{ws}}$ had strong positive correlation with EC and chloride content and positive significant correlations with water soluble $\mathrm{Ca}$ and $\mathrm{Na}$. Positive correlations were found between $\mathrm{K}_{\mathrm{ws}}$ with $\mathrm{C}$, organic matter, $\mathrm{Ca}_{\mathrm{ws}}, \mathrm{Na}_{\mathrm{ws}}, \mathrm{Cl}^{-}$and $\mathrm{S}_{\mathrm{ws}}$.

Table 2. Summary of analysis of variance of different variables of soil in three locations of three islands.

\begin{tabular}{|c|c|c|c|c|c|}
\hline Variables & $\mathrm{F}$ & $\mathrm{P}$ & Variables & $\mathrm{F}$ & $\mathrm{P}$ \\
\hline Moisture & & & $\mathrm{Ca}_{w s}$ & & \\
\hline Island & 37.66 & $<0.0001$ & Island & 14.69 & 0.008 \\
\hline Location & 1.98 & 0.154 & Location & 1.82 & 0.001 \\
\hline Interaction & 4.62 & 0.0046 & Interaction & 1.18 & 0.41 \\
\hline $\mathrm{pH}$ & & & $\mathrm{Mg}_{\mathrm{ws}}$ & & \\
\hline Island & 7.92 & 0.0016 & Island & 6.63 & 0.004 \\
\hline Location & 0.28 & 0.758 & Locatio & 1.69 & 0.199 \\
\hline Interaction & 1.82 & 0.15 & Interaction & 2.27 & 0.083 \\
\hline Conductivity & & & $\mathrm{S}_{\mathrm{sw}}$ & & \\
\hline Island & 12.91 & $<0.0001$ & Island & 35.55 & $<0.0001$ \\
\hline Location & 1.21 & 0.311 & Location & 7.53 & 0.002 \\
\hline Interaction & 2.08 & 0.106 & Interaction & 1.49 & 0.229 \\
\hline $\mathrm{N}_{\text {tot }}$ & & & & & \\
\hline Island & 0.08 & 0.92 & Island & 9.07 & 0.0008 \\
\hline Location & 7.25 & 0.0025 & Location & 0.05 & 0.956 \\
\hline Interaction & 7.28 & 0.0003 & Interaction & 1.08 & 0.384 \\
\hline $\mathrm{P}_{\text {tot }}$ & & & $\mathrm{C}$ & & \\
\hline Island & 1.19 & 0.318 & Island & 5.15 & 0.011 \\
\hline Location & 0.48 & 0.621 & Location & 2.71 & 0.08 \\
\hline Interaction & 1.14 & 0.356 & Interaction & 3.77 & 0.013 \\
\hline$K_{\text {tot }}$ & & & $\mathrm{OM}$ & & \\
\hline Island & 13.56 & $<0.0001$ & Island & 5.15 & 0.011 \\
\hline Location & 2.12 & 0.136 & Location & 2.71 & 0.08 \\
\hline Interaction & 0.47 & 0.757 & Interaction & 3.77 & 0.013 \\
\hline$S_{\text {tot }}$ & & & $\mathrm{Cl}^{-}$ & & \\
\hline Island & 3.22 & 0.053 & Island & 24.85 & $<0.0001$ \\
\hline Location & 1.22 & 0.309 & Location & 0.13 & 0.88 \\
\hline Interaction & 2.70 & 0.048 & Interaction & 2.3 & 0.08 \\
\hline \multicolumn{6}{|l|}{$\mathrm{K}_{\mathrm{ws}}$} \\
\hline Island & 21.36 & $<0.0001$ & & & \\
\hline Location & 0.19 & 0.825 & & & \\
\hline Interaction & 0.92 & 0.467 & & & \\
\hline
\end{tabular}



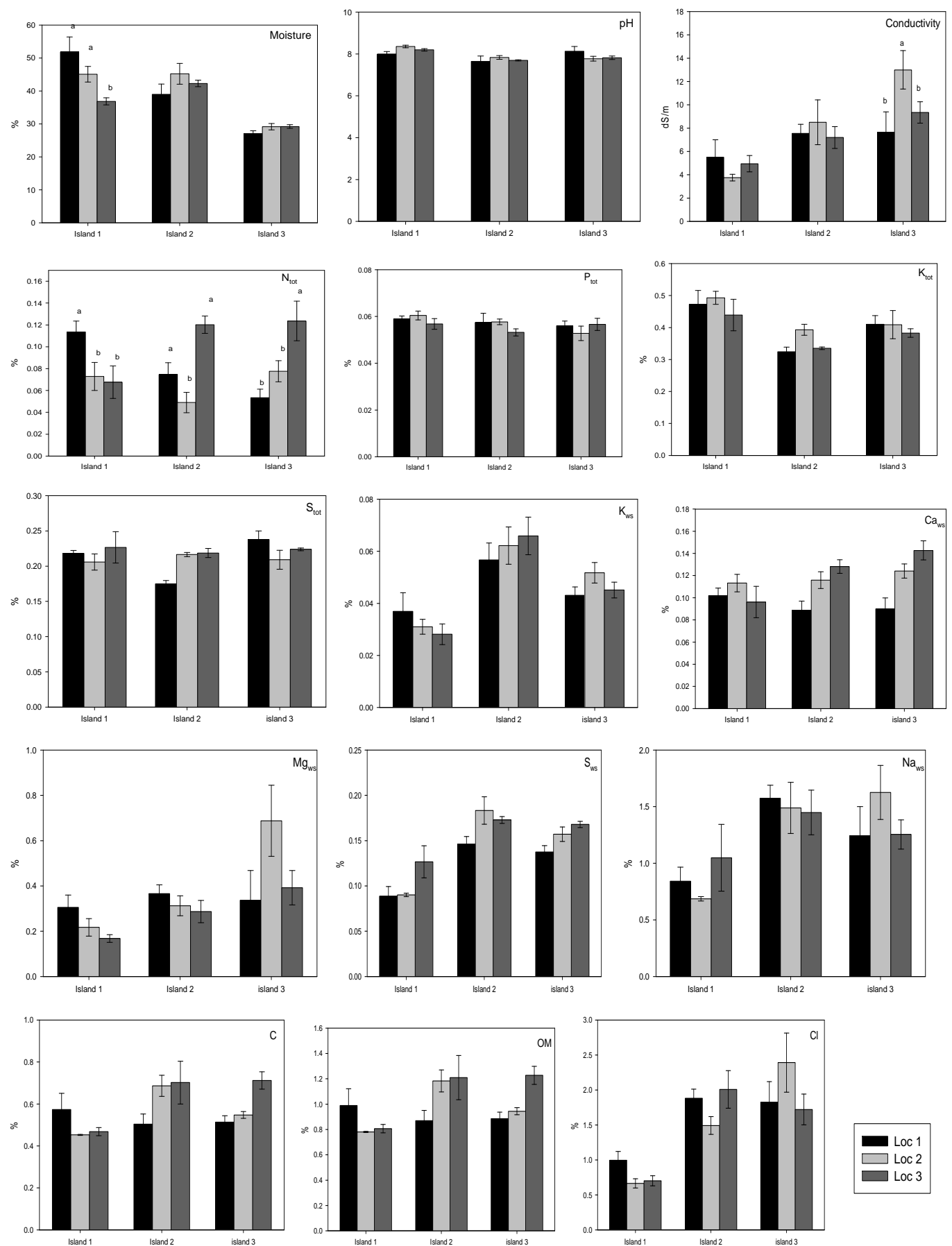

Fig. 4. Location wise variations in the different variables of soil samples in three islands with \pm 1 standard error. Different letters at the top of the bars showed that they are significantly different at the $\mathrm{p}=0.05$ level. 


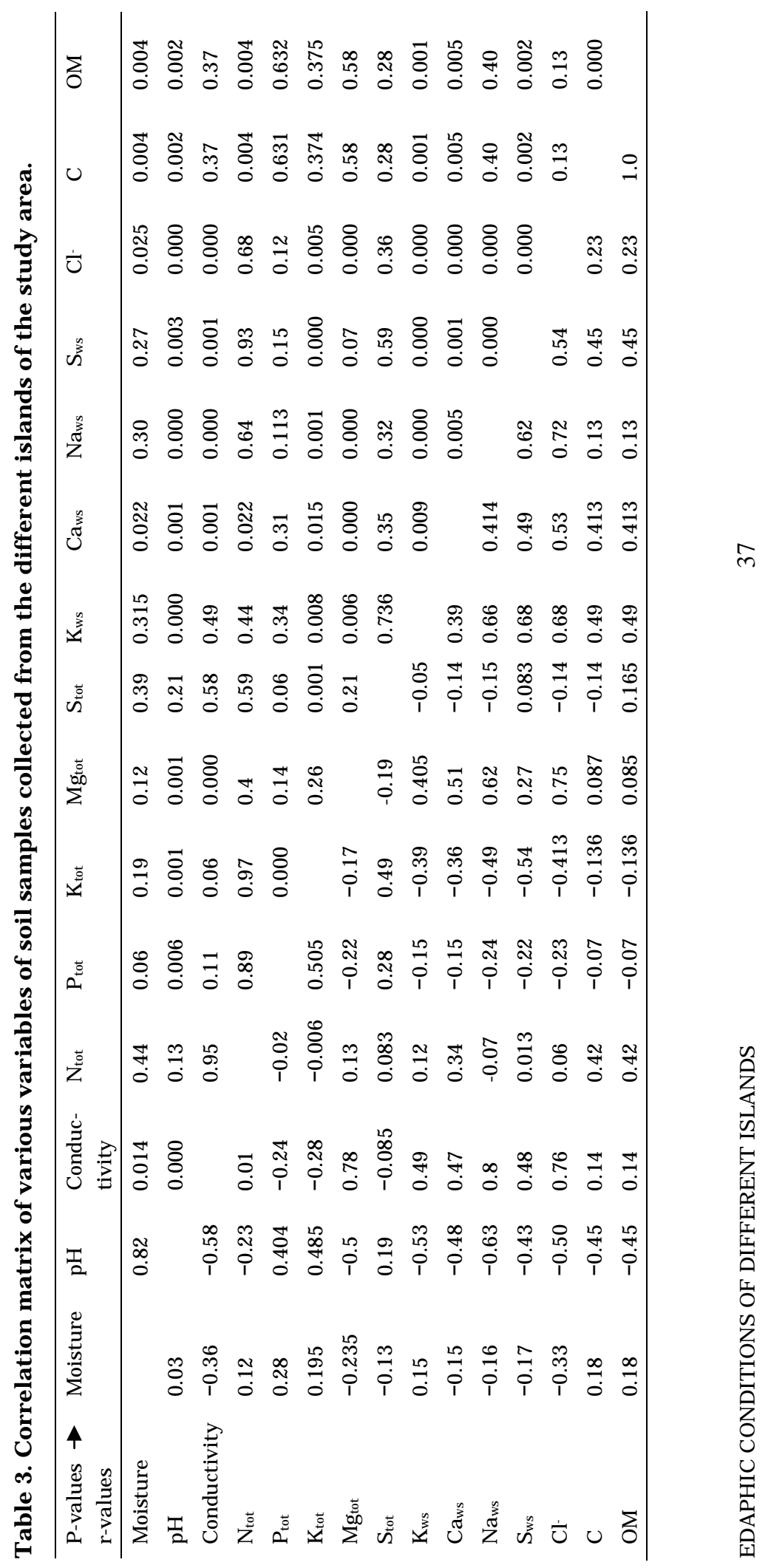


Factors responsible for variation in edaphic features: The result presented here showed that the soils of the islands were fairly homogeneous as regards to soil chemistry. Soil analysis did not show general patterns of spatial variations among the islands and within the islands. The results thus indicate that broad-scale hydrology did not appear to be responsible for differences found in the edaphic variables.

Moderate significant positive correlation between $\mathrm{N}_{\text {tot }}$ and organic matter suggested that input source of $\mathrm{N}_{\text {tot }}$ is organic matter. A decrease in $\mathrm{N}_{\text {tot }}$ content from seawards to landwards (location 1 to location 3) was found in Island I but opposite trend was observed in Island III i.e. from location 3 to location 1 (this Island had no landward connection like Island I). Organic matter content of soil samples of different locations of Island III followed the same pattern as $\mathrm{N}_{\text {tot }}$ and although location 1 of Island I had highest value, location 3 showed intermediate value in organic matter content showing different pattern of distribution. The lower values of organic matter in Islands I and II may be attributed to the tidal flashing out of the leaf litters. The lower values found in the Island III can be explained by the fact that grazing is common in this island by buffalo of the local people. Mangrove ecosystems of subtropical and tropical regions are highly productive (14) that provide organic matter and function and structure are influenced by hydrodynamics and soil properties. ${ }^{(15)}$

Electrical conductivity was higher in seaward islands, i.e. Island III had the maximum values followed by Islands II and I. The mixing of fresh water with saline water near island I and diurnal inundation of the island I by this diluted water might have resulted lower values. On the other hand island III is not inundated during daily tides but have had higher accumulation of salt, however, the reason for this remain unidentified. Conductivity of the water samples near the Island III (for water sample location 3) were about two times higher than those of the water samples of location 1 near Island I (unpublished data). Tam and Wong (1998)(15) observed higher conductivity values during dry winter season than summer when fresh water from rainfall during summer diluted the salt concentration. Soil samples of the present study were collected during the end of dry winter season before the commencement of rain. Conductivity values of the present study were much higher than some other mangroves of nearby areas. ${ }^{(15-17)}$ Soil $\mathrm{pH}$ values of the different islands were found to be neutral to alkaline (6.7 to 8.99). Higher $\mathrm{pH}$ values found in the present study could be explained by the lack of mangrove litter.(15)

Soils of mangroves had been considered as homogeneous entities where different physical factors such as tidal amplitude, period of inundation, microtopography had been explained as the responsible reasons for variation. But different studies in the last few years had indicated that the presence of different mangrove species were the 
other responsible factors for the variability of different soil parameters. ${ }^{(18)}$ For examples, variations in sulphide content ${ }^{(19)}$, acidity ${ }^{(20)}$, total organic matter content and trace metals ${ }^{(21)}$ were found in soils that were dominated by different mangrove species. Capacity of different mangrove species to change the conditions of the adjacent soil of their root systems had also been found responsible. ${ }^{(19,21)}$ Mangrove litters with different organic composition might also have caused the variation in the soil conditions. ${ }^{(22)}$ The variations found in the soil variables of the present study might be explained due to the physical factors such as amplitude and duration of tidal inundation and further study is needed to comment on the capacity of Sonneratia apetala, planted and growing extensively in the coastal islands, including the islands studied, to change the soil conditions adjacent to their root systems.

\section{Acknowledgements}

The authors gratefully acknowledge the financial support provided by the authority of Dhaka University, Bangladesh and the Norwegian University of Life Sciences, Ås, Norway. The help of Mr. Daniel Mushi in statistical analysis of data is also acknowledged. They also thank the staffs of Bangladesh Forest Research Institute, Rangabali station, Patuakhali district for field assistance.

\section{References}

1. Wolanski E, L Chicharo, MA Chicharo and P Morais 2006. An ecohydrology model of the Guadiana Estuary (South Portugal). Estuarine, Coastal and Shelf Science 70: 132-143.

2. Lindeboom H 2002. The coastal zone: an ecosystem under pressure. In: Oceans 2020: Science, Trends, and the Challenge of Sustainability (Field, JG, G Hempel and CP Summerhayes Eds.), pp. 49-84.

3. Krey JBB 1976. Phytoplankton production atlas of the international Indian Ocean expedition. pp.70. IOC/UNESCO.

4. Wyritki K 1971. Oceanographic atlas of the international Indian Ocean expedition. Pp531 National Science Foundation, Washington, DC.

5. Chaudhuri $\mathrm{AB}$ and $\mathrm{A}$ Chaudhuri 1994. Mangrove of the Sundarbans. Volume 1: India. IUCN, Bangkok.

6. Karim A 1994. The physical environment. In: Mangrove of the Sunderbans (Hussain Z and G Achanya Eds), Vol 2. Bangladesh. pp. 11-42. IUCN, Bangkok.

7. Khan ZH, MS Hussain and AR Muzumder 1998. Properties of soils from the offshore islands of Bangladesh. Bangladesh J. F. Sci. 27: 114-120.

8. Ali A 1999. Climate change impacts and adaptation assessment in Bangladesh. Clim. Res. 12: $109-116$.

9. Hossain MS 2001. Biological aspects of coastal and maritime environment of Bangladesh. Ocean Coast Manage 44: 211-282.

10. Hunt J 1980. Determination of total sulphur in small amount of plant material. Analyst 105: 83-85. 
11. Piper CS 1950. Soil and Plant Analysis. University of Adelaide.

12. Jackson ML 1973. Soil chemical analysis. Constable and Co. Ltd, London.

13. Walkley A and IA Black 1934. An examination of the Degtjareff method for determining soil organic matter and a proposed modification of the chromic acid titration method. Soil Sci. 37: 29-38.

14. Boto KG 1992. Pollution in Tropical Aquatic Systems. In: Connell DW, Hawker DW (ed), Ann Arbor London: CRC Press Inc. pp. 129-145.

15. Tam NFY and YS Wong 1998. Variations of soil nutrient and organic matter content in a subtropical mangrove ecosystem. Water, Air Soil Poll. 103: 245-261.

16. Tam NFY, SH Lie, CY Lane, GZ Chen, MS Li and YS Wong 1995. Nutrients and heavy metal contamination of plants and sediments in Futian mangrove forest. Hydrobiologia 295: 149-158.

17. Tam NYF, LLP Vrijmoed, SH Li and YS Wong 1993. The chemical properties of soil and its association with litter and plant production in a sub-tropical mangrove community in Hong Kong. Proc. Int. Conf. on Marine Biology of Hong Kong and the South China Sea. Hong Kong, October 1993.

18. Lacerda LD, V Ittekkotb and SR Patchineelama 1995. Biogeochemistry of Mangrove Soil Organic Matter: a Comparison Between Rhizophora and Avicennia Soils in Southeastern Brazil. Estuari Coast Shelf Sci. 40: 713-720.

19. Nickerson NH and FR Thibodeau 1985. Association between porewater sulfide concentrations and the distribution of mangroves. Biogeochemistry 1:183-192

20. Naidoo GM 1980 Mangrove soils of the beach wood area, Durban. S. Afr. J. Bot. 46 : 293-304

21. Thibodeau FR and NH Nickerson 1986. Differential oxidation of mangrove substrate by Avicennia germinans and Rhizophora mangle. Amer. J. Bot. 73: 512-516.

22. Benner R, PG Hatcher and JI Hedges 1990. Early diagenesis of mangrove leaves in a tropical estuary: bulk chemical composition characterization using solid-state 13C NMR and elemental analysis. Geochim Cosmochim Acta. 54: 2003-2013

(Manuscript received on 2 April, 2009; revised on 13 June, 2009) 